Foro Interno. Anuario de Teoría Política

ISSN: 1578-4576

\title{
Lefort y la Revolución húngara de 1956. La singularidad teórico- política de su interpretación
}

\author{
Leonardo Eiff ${ }^{1}$
}

Recibido: 23 de marzo de 2015 / Aceptado: 26 de noviembre de 2015

Resumen. El artículo analiza el impacto de la Revolución húngara de 1956 en el pensamiento político de Claude Lefort desde sus comienzos como intelectual y militante de una organización revolucionaria hasta su consagrada teorización acerca de la democracia en contraposición con el totalitarismo. Para ello, el artículo reconstruye los rasgos principales de la Revolución húngara y recoge tres interpretaciones del suceso - la de Jean Paul Sartre, Raymond Aron y Hannah Arendt- a fin de contrastarlas con la de Claude Lefort; también, con idéntico fin, indaga las discrepancias en el seno de Socialisme ou barbarie ocasionadas como consecuencia del acontecimiento húngaro. En el plano teórico-político, el artículo pretende mostrar la relación estrecha entre democracia, revolución y emancipación en la noción de democracia salvaje movilizada por Lefort, revelando la existencia de un hilo conductor entre la ponderación lefortiana de la Revolución húngara y dicha noción crucial.

Palabras clave: Revolución; democracia; emancipación; Claude Lefort; Hungría.

\section{[en] The Theoretical-Political Singularity of Lefort's Interpretation of the Hungarian Revolution of 1956}

\begin{abstract}
This article analyses the impact of the 1956 Hungarian revolution on the political thought of Claude Lefort, from his beginnings as an intellectual and activist in a revolutionary organization until his widely read theorizing of democracy as opposed to totalitarianism. The article reconstructs the main features of the Hungarian revolution and offers three interpretations of the event - that of Jean Paul Sartre, that of Raymond Aron and that of Hannah Arendt - in order to contrast them with Claude Lefort's own interpretation. Along similar lines, the author explores the discrepancies within Socialisme ou barbarie as a result of the events in Hungary. From the political theory perspective, the article aims to show the close relationship between democracy, revolution and emancipation in the notion of savage democracy used by Lefort, revealing the existence of a common thread that runs from the significance of the Hungarian revolution to that crucial notion.
\end{abstract}

Keywords: Revolution; democracy; emancipation; Claude Lefort; Hungary.

Cómo citar: Leonardo Eiff, "Lefort y la Revolución húngara de 1956. La singularidad teórico-política de su interpretación": Foro Interno. Anuario de Teoría Política, vol. 16 (2016), pp. 123-145.

1 Universidad Nacional General Sarmiento - CONICET (Argentina).
E-mail: leoeiff@yahoo.com.ar 
Bref Machiavel m'a instruit, il m'instruit toujours, parce qu'on trouve chez lui une triple critique: celle de la tyrannie, celle du conservatisme bourgeois au service d'intérêts oligarchiques, celle de l'idéalisme républicain ou démocratique qui masque la place du pouvoir et la permanence du conflit ${ }^{2}$.

Claude Lefort, Le temps présent.

\section{Introducción}

El presente trabajo se inscribe en el marco de un proyecto de investigación que intenta dilucidar la particular ruptura de Claude Lefort (1924-2010) con su etapa marxista, preguntándose por las posibles continuidades dentro de una obra de pensamiento signada por el alejamiento de la juvenil etapa revolucionaria. Contrariamente a nuestro intento de hallar hilos de continuidad, existe una corriente interpretativa representada, por ejemplo, por los trabajos de Bernard Flynn ${ }^{3}$, Oliver Marchart ${ }^{4}$, Hugues Poltier ${ }^{5}$, Esteban Molina ${ }^{6}$ y Martín Plot ${ }^{7}$, que tienden a dividir la obra de Lefort en dos momentos sin prácticamente ninguna conexión de sentido, o conectados por un divorcio. Así, habría una etapa "arqueológica" que se condensaría en la militancia marxista de nuestro autor, y solo tendría un significado negativo: como la etapa que fue necesario dejar atrás para configurar el verdadero pensamiento político de Lefort. El denominado "marxismo" de Lefort es, entonces, relegado a un contexto inicial, precario, de la reflexión, casi a un error producto del fervor militante (recordemos que nuestro autor militó en la sección francesa de la IV Internacional trotskista y luego fundó, en 1949, la revista Socialisme ou barbarie), surgido de la resistencia francesa a la ocupación nazi y del aura que irradiaba la llamada política revolucionaria. No obstante, el rasgo medular de este conjunto de interpretaciones sobre la obra de marras radica en la articulación que presupone con una manera particular de explicar y comprender el cambio que se produce, en relación a la crisis de legitimidad de la llamada politica revolucionaria, alrededor de los años setenta. En rigor, estas interpretaciones entienden que el cisma político, conceptual e intelectual, que se suscita sobre la idea de "Revolución" constituye un auténtico parteaguas que explicaría el abandono, por parte de una franja significativa del campo intelectual de las "izquierdas", de la "ilusión marxista". De esta manera, las críticas que comienzan a dirigirse contra la teoría marxista son subsumidas, por esta corriente de interpretación, en un marco de cambio de época, que puede resumirse a partir de la figura del pasaje de "la revolución a la democracia". Entendemos, por

2 "En suma, Maquiavelo me lo ha enseñado, me lo enseñó siempre, puesto que hallamos en él una triple crítica: de la tiranía, del conservadurismo burgués al servicio de intereses oligárquicos, del idealismo republicano o democrático que soslaya el lugar del poder y la permanencia del conflicto". Claude Lefort, Le temps present, Écrits 1945-2005, Belin, Paris, 2007, p. 361.

Bernard Flinn, Lefort y lo político, Prometeo, Buenos Aires, 2008.

4 Olivier Marchart, El pensamiento politico post-fundacional, FCE, Buenos Aires, 2009.

Hugues Poltier, Lefort y el descubrimiento de lo político, Nueva Visión, Buenos Aires, 2003.

Esteban Molina, Le défi du politique. Totalitarisme et démocratie chez Claude Lefort, L'Harmattan, Paris, 2005. Martín Plot, La carne de lo social, Prometeo, Buenos Aires, 2008.

Noberto Lechner, "De la revolución a la democracia", en Los patios interiores de la democracia: subjetividad y política, FCE, México, 1995, pp. 17-38. 
nuestra parte y en términos generales, que dicha subsunción impide observar los matices que se producen en el contexto de ese cambio de época. La construcción de una frontera imaginaria entre los autores y textos que pertenecen a la "época de la revolución" y los que han realizado la crítica de la misma y, como consecuencia de ella, han abrazado la causa filosófica y política de la democracia, obtura la pluralidad de vasos comunicantes entre ambos períodos y tiende a reducir la complejidad de la obra lefortiana al someterla a la macro explicación del pasaje de "la revolución a la democracia".

En este trabajo, para revelar la riqueza del trayecto teórico-político de Lefort y nuestra discrepancia con las interpretaciones arriba resumidas, nos proponemos rastrear las sucesivas interpretaciones del pensador francés de un acontecimiento crucial del siglo veinte: la Revolución húngara de 1956. En efecto, Claude Lefort pensó intensamente el suceso húngaro del 56 y lo consideró - tanto en su etapa "marxista" como en su etapa "democrática"- un revelador histórico, es decir, una especie de visor desde donde atisbar las contradicciones de la modernidad y la irrupción de la revolución democrática. Para Lefort, estamos frente a la primera "revolución anti-totalitaria", cuyo efecto dispara la posibilidad de pensar en una noción libertaria de la democracia. Vale aclarar que nosotros no pretendemos soslayar la densidad teórico-política que posee la crítica lefortiana al marxismo para la forja de su pensamiento acerca de la experiencia democrática. No obstante, procuraremos indagar los sentidos teóricos y políticos que extrajo Lefort de la Revolución húngara, plasmados en el primer escrito ${ }^{10}$ — producido al calor de los acontecimientos y en el contexto del cisma político que ocasionaron dichos sucesos en el seno de la izquierda intelectual francesa y europea-, y cuya continuidad en los posteriores ensayos destinados al mismo objeto elaborados en la década de los setenta ${ }^{11}$, en el cuadro de su conocida teorización acerca de la oposición entre la democracia y el totalitarismo, es notoria.

Entonces, nuestro objetivo persigue un estudio de las sucesivas lecturas lefortianas de la Revolución húngara a fin de iluminar su singularidad y su lugar crucial en el entramado teórico-político desplegado por el autor francés. Así, dicha lectura medular, nos gustaría sugerir, se ubica más allá de la temática de la ruptura con el marxismo y permite vislumbrar la paulatina irrupción de la noción de democracia pergeñada por Lefort. Nuestra interpretación sigue la propuesta de lectura de Miguel Abensour $^{12}$, quien no solo revela el hiato conceptual y político entre los dos períodos de la obra lefortiana, sino que también esgrime una preocupación por el modo en que se elabora esa rajadura y por los sentidos que esparce el vínculo entre Karl Marx (1818-1883) y Nicolás Maquiavelo (1469-1527) en la constelación teórica de la democracia salvaje ensayada por Lefort. Desde los trabajos de Abensour situamos nuestra perspectiva teórico-política: cesar de pensar la política asociada al problema del orden (romper con la tradición hobbesiana) para concebir la institución de lo político como un conjunto de relaciones, instauración de una constellation de liens; para ello Abensour sugiere tres indicaciones:

\footnotetext{
Claude Lefort, "La première révolution antitotalitaire”, en Le temps présent. Écrits 1945-2005, pp. 301-308.

Claude Lefort, "L'insurrection hongroise" : Socialisme ou barbarie, n. ${ }^{\circ} 20$ (diciembre 1956), pp. 85-116.

Claude Lefort "Hongrie 1956. Un révélateur historique" y "La première révolution antitotalitaire", en Le temps présent. Écrits 1945-2005, pp. 261-265; pp. 301-308.

12 Miguel Abensour, Pour une philosophie politique critique, Sens \& Tonka, Paris, 2009, passim.
} 
La diferencia entre política y dominación, la oposición en cualquier ciudad humana entre el deseo de libertad y el deseo de dominación; la especificidad, la heterogeneidad irreductible de la política; la permanencia del conflicto, de la división tan persistente como la utopía ${ }^{13}$.

Ahora bien, a fin de destacar aún más la singular lectura lefortiana de la Revolución húngara proponemos dos cuestiones colindantes: por un lado, contrastarla con una serie de interpretaciones destacables del mismo acontecimiento y, por el otro lado, enraizarla en el contexto de la discusión que entabló nuestro autor con Cornelius Castoriadis (1922-1997) con motivo de la orientación que debía seguir el proyecto político e intelectual de Socialisme ou barbarie. En primer lugar, vamos a exponer, con cierta exhaustividad, las posiciones de Jean Paul Sartre (1905-1980), Raymond Aron (1905-1983) y Hannah Arendt (1906-1975) frente al acontecimiento húngaro; se trata, por supuesto, de interpretaciones discrepantes entre sí y por demás sugerentes, cuyos sentidos condensan las variaciones teóricopolíticas disponibles para reaccionar de cara a los sucesos, más allá del sentido común ideológico. En el caso de Sartre: la renovación del marxismo y el reformismo de izquierda; en el de Aron: el liberalismo realista, maquiaveliano y weberiano; y en el de Arendt: el republicanismo, peculiarmente consejista. Por otra parte, los autores fueron seleccionados por su cercanía - mayormente coincidente o discrepantecon el derrotero lefortiano. En ese marco, el objetivo es, como dijimos, iluminar la singularidad de la mirada teórico-política de Lefort cotejándola con la de los tres autores, quienes, como nuestro autor, se sintieron urgidos a reflexionar con motivo de la Revolución húngara.

En segundo lugar, nos interesa rastrear la polémica abierta entre Lefort y Castoriadis a raíz de las consecuencias divergentes que extrajeron la Revolución húngara. Ambos compartieron el diagnostico global — por eso vamos a permitirnos presentar el texto de Lefort "L'insurrection hongroise" como expresión del colectivo Socialisme ou barbarie-; no obstante, el intento de hallar un correlato teórico, político y organizativo a partir de la novedad húngara reavivó la discrepancia entre los antiguos compañeros (llegado el momento repondremos las etapas de la discusión) y produjo el alejamiento definitivo de Lefort de Socialisme ou barbarie ${ }^{14}$. El sentido de la incursión en la polémica es revelar el lugar crucial que tuvo el suceso húngaro para su reavivamiento e identificar en ella los rasgos singulares del itinerario recorrido por Lefort, quien, aunque la polémica se enmarque dentro del discurso marxista, desde entonces delata una peculiar perspectiva que anuncia la posterior teorización acerca de la experiencia democrática.

En fin, el objetivo del presente trabajo es rastrear los hilos de continuidad dentro de la trayectoria teórico-política de nuestro autor e hilvanar una interpretación de la misma que escape a la periodización basada en la ruptura con el marxismo, porque con ella se extravía el sugerente vínculo lefortiano entre democracia, revolución

13 "La différence entre politique et domination, l'opposition dans toute cité humaine entre le désir de liberté et le désir de domination; la spécificité, l'hétérogénéité irréductible de la politique; la permanence du conflit, de la division aussi persistants que l'utopie". Ibid., pp. 45-46.

14 Para una interpretación completa del proyecto político e intelectual de Socialisme ou barbarie y una cabal reconstrucción de esta polémica, véase Marie-France Raflin, "Socialisme ou barbarie: du vrai communisme à la radicalité", tesis doctoral presentada el 13 de abril de 2005, Institut d'études politiques de Paris. Disponible en: http://spire.sciencespo.fr/hdl:/2441/53r60a8s3kup1vc9kd4rhb0q4/resources/raflin-scpo-2005.pdf (septiembre 2016). 
y emancipación ${ }^{15}$, que, siguiendo a Abensour, nos parece decisivo explorar. Para ello, optamos por reconstruir el vínculo de Lefort con la Revolución húngara, no para teorizar acerca del posible impacto de un acontecimiento histórico en una reflexión conceptual — de allí que nuestro interés se enfoca en cotejarlas con otras interpretaciones, para calibrar la distinción de su reflexión política-, sino para resaltar cómo Lefort anuda la singularidad de la Revolución húngara con su sintomática imaginación teórico-política para pensar el advenimiento moderno de la democracia y la revolución.

Ahora bien, antes de adentrarnos en el meollo de nuestra propuesta consideramos conveniente pesquisar el sentido político de la Revolución húngara, obviando, en lo posible, la narración de hechos ya $\operatorname{conocidos}^{16}$.

La reconstrucción histórica del acontecimiento exige situarlo en el contexto explosivo de la desestalinización, que, para François Furet (1927-1997), inaugura "el principio del fin" ${ }^{17}$ del comunismo. El intento diseñado por Nikita Jruschov (18941971) de una transición ordenada y controlada desde arriba que permitiera morigerar los efectos más devastadores del período estalinista sin poner en peligro los resortes capitales del régimen soviético, no pudo garantizarse en el resto del llamado campo socialista; allí, apunta Tony Judt (1948-2010): “el impacto de la supuesta apostasía de Jruschov hacia Stalin fue más que espectacular"18. En efecto, sobre todo en Polonia y en Hungría, desató una fuerza centrífuga, que pudo reencauzarse a tiempo — desde el punto de vista del sostenimiento del poder comunista, claro está- en el primer caso, pero no en el segundo, donde desembocó en una insurrección popular masiva. Tanto Furet como Judt destacan que lo que desencadenó la reacción represiva soviética fue menos la puesta en cuestión de las bases socialistas del régimen o incluso la salida de Hungría del Pacto de Varsovia, que el abandono del partido húngaro del monopolio del poder, el fin de su papel protagónico - algo que en Polonia, Wladislaw Gomulka (1905-1982) se cuidó bien de conservar- El comunismo no podía permitirse esa ruptura, dice Judt, "porque era la rendija por la que podía penetrar la democracia que llevaría a la perdición a los partidos comunistas del resto del mundo"19. Se trata, como se observa, de lecturas políticas, que enfatizan la contraposición entre la democracia y el totalitarismo y concluyen que, a diferencia de la izquierda occidental, que pudo paliar su desazón revolucionaria con el despertar del Tercer Mundo, a partir de noviembre de 1956 el comunismo en el Este "comenzó su descenso hacia un ocaso de estancamiento, corrupción y cinismo que habría de durar varias décadas" 20 . Por el contrario, interpretaciones historiográficas más sociales, como la de Eric Hobsbawm

15 Un ejemplo de ello es el artículo de Matías Sirczuk, "La invención democrática. Una lectura de Lefort": Las Torres de Lucca, vol. 3, n. 5 (julio-diciembre 2014), pp. 7-23. Sirczuk reconstruye con brío la difícil noción de democracia en Lefort, pero se limita a señalar la distancia del autor con el marxismo sin interrogar sus "escritos marxistas" ni preguntarse si su insistencia en vincular la democracia con la crítica del orden instituido puede explicarse, de alguna manera, a partir de una sensibilidad teórica y política que comenzó a perfilarse en su "momento" marxista y militante.

16 Para una narración pormenorizada de los mismos véase: François Fejtö, La tragédie hongroise, Pierre Horay, Paris, 1956; François Fejtö, Budapest 1956: la révolution hongroise, René Julliard, Paris, 1966; Miklós Molnár, Victoire d'une défaite: Budapest, 1956, Paris, L'Age de 1'homme, 1996; Paul Kecskeméti, The Unexpected Revolution. Social Forces in the Hungarian Uprising, Stanford Press, Stanford, 1961; Agnes Heller y Ferenc Feher, Análisis de la revolución húngara de 1956, Hacer, Barcelona, 1983.

17 François Furet, El pasado de una ilusión. Ensayo sobre la idea comunista en el siglo XX, FCE, México, 1995, cap. XII.

18 Tony Judt, Postguerra. Una historia de Europa desde 1945, Madrid, Taurus, 2006, p. 311.

19 Ibid., p. 319.

$20 \quad$ Ibid., p. 321. 
(1917-2012), quien rehúsa calificar como totalitarios a los regímenes comunistas ${ }^{21}$, destaca las penurias sociales y económicas que sufrieron los países del Este europeo durante el estalinismo, con Hungría en un lugar destacado ${ }^{22}$, a causa de la brutal imposición de un modelo único altamente autoritario que, sin embargo, suscitó a la larga una evidente modernización de la sociedad. Hobsbawm considera, como Furet y Judt, que la muerte de Iósif Stalin (1878-1953) y el comienzo de la desestalinización germinaron el inicio del desmembramiento del bloque comunista, pero falto de una perspectiva política tiende a soslayar el rasgo singular de la Revolución húngara al situarla en la explicación general acerca de la imposibilidad constitutiva de los regímenes comunistas para acometer reformas de calado capaces de remozar el sistema sin destruirlo.

Por otra parte, la insurrección húngara $\mathrm{y}$, sobre todo, su aplastamiento manu militari causó un impacto notable, fue una especie de onda expansiva en la conciencia crítica de la izquierda europea. En Francia, el apoyo irrestricto del Partido Comunista a la intervención — sus dirigentes vieron "en los acontecimientos de Hungría la justificación de su resistencia a la desestalinización"23 - desencadenó una extendida polémica entre las diversas versiones de la izquierda ${ }^{24}$ (lo veremos en el escrito de Sartre y en los de Lefort y Castoriadis), el Partido francés tuvo su primer cimbronazo, aunque moderado y refrenado eficazmente por la dirección ${ }^{25}$; en cambio, como sugiere Judt, en los países sovietizados, y en algunos europeos, como Inglaterra ${ }^{26}$, significó el inicio de la pérdida del aura, el resquebrajamiento de la promesa comunista: el comunismo comenzó a ser asociado a la represión antes que a la revolución. En su momento, Merleau-Ponty lo resumió, algo enigmáticamente, así: "algo pasa en la historia del comunismo"27.

Las interpretaciones políticas de Judt y Furet, deudoras de las reflexiones aronianas acerca del derrotero del siglo veinte, perspicaces en varios sentidos, tienden a menoscabar, sin embargo, la potente radicalidad de la Revolución húngara, que desborda su encapsulamiento dentro de la historia del comunismo. En este sentido, Judt y Furet, en el espejo de la historia, reponen la distinción entre revolución y democracia, que nosotros nos proponemos discutir en el contexto de las interpretaciones del derrotero de la obra de Lefort, cuya conclusión, liberal, empequeñece la magnitud de la Revolución húngara. Por el contrario, otras interpretaciones - que se abren paso entre el discurso histórico, la narración periodística y el testimonio político-, como las de François Fejtö y Miklós Molnár ${ }^{28}$, quienes, atentos a las declaraciones de los círculos y consejos ${ }^{29} \mathrm{y}$ al despliegue efectivo de los sucesos, enfatizan la politicidad

21 Eric Hobsbawm, Historia del siglo XX, Buenos Aires, Crítica, 1998, p. 393.

22 Para una historia económica de Europa durante el siglo veinte que muestra las duras condiciones económicosociales y la escasez de bienes de consumo en países como Hungría, durante la década de los cincuenta, véase Derek Aldcroft, Historia de la economía europea 1914-2000, Crítica, Barcelona, 2003, cap. 6.

23 Sarolta Kleja'nsky, "Le parti communiste français et l'intervention soviétique en Hongrie", en Le parti communiste français et l'année 1956, Actes des journées d'étude organisées par les archives départementales de la Seine-Saint Denis, Mémoire en ligne, 2007, p. 95. Disponible en: http://www.gabrielperi.fr/assets/files/pdf/ Le_PCF_et_1_annee_1956.pdf (septiembre 2016).

24 David Caute, Les compagnons de route 1917-1968, Lafont, Paris, 1975.

25 Véase Kleja'nsky, "Le parti communiste français et l'intervention soviétique en Hongrie”, p. 99.

26 Ibidem. El partido británico perdió cerca del $20 \%$ de sus adherentes.

27 Maurice Merleau-Ponty, Signes, Gallimard, Paris, 1960, p. 348.

28 Fejtö, Budapest 1956: la révolution hongroise y Molnár, Victoire d'une défaite: Budapest, 1956.

29 El resumen de las declaraciones de algunos de los grupos insurrectos sería el siguiente:

Círculo Petöfi: 1) Retirada de las tropas soviéticas de Hungría. 2) Completa libertad de palabra y de prensa. 3) Un congreso general del partido comunista para que en él se eligiera un nuevo líder. 4) Convocatoria a elec- 
de la insurrección y su trágica enseñanza para la modernidad tout court, a partir del asombroso entramado forjado entre la libertad política y el socialismo obrero, que, en acto, suscitó la acción insurreccional. Lefort - quien, por otra parte, realizó una eficaz crítica del ensayo de Furet, que podemos extender a la historiografía del comunismo tras su derrumbe: idealista, moralista, ciega ante lo político ${ }^{30}$ — estaría más cercano a estas interpretaciones, puesto que el vigor de la insurrección desfondó las clásicas distinciones modernas sobre qué es político y qué no; la práctica insurreccional húngara reunió tradiciones de pensamiento que el siglo veinte pareció bifurcar irremediablemente; fue un estuario donde pudo desembocar, por ejemplo, el pluralismo político y el control obrero de la producción, o, por el revés de la trama, fulminó el dominio del partido único, a partir de garantizar elecciones libres y las libertades públicas de expresión y asociación, y también trazó un programa obrero y socialista: limitación de la jerarquía, supresión de las normas de trabajo, gestión obrera de las fábricas. Pues bien, hacia ese pendant, complejo y agónico, de la Revolución húngara, focaliza Lefort, y hacia ese punto vamos a dirigir nuestra atención.

Sin embargo, como todo acontecimiento, y aun compartiendo un enfoque sustentado en la originalidad de los eventos, suscitó una disputa de interpretaciones. Como ya adelantamos, comenzaremos con las de Sartre, Aron y Arendt para luego, pasando por la polémica con Castoriadis, cotejarlas con la de Lefort e intentar asir su singularidad.

\section{Tres lecturas}

\subsection{Salvar la promesa socialista}

En el ensayo que dedica Sartre a los acontecimientos de Hungría, El fantasma de Stalin $^{31}$, pueden visualizarse rápidamente las tres intenciones que hilvanan el texto y que, al mismo tiempo, lo sitúan en una insuperable contradicción: condenar la intervención soviética, responsabilizar a la política estalinista aplicada en los países del Este de la crisis en Hungría y salvar al socialismo, como idea y como proyecto concreto iniciado en octubre de 1917.

La condena es vigorosa. Hay una fuerza en el rechazo. Se percibe la indignación ante las matanzas, edulcoradas por las insoportables mentiras de los dirigentes

ciones libres, permitiendo presentarse a todos los partidos del Frente popular. 5) Relaciones de amistad con la URSS, pero sobre nuevas bases. 6) Una Hungría socialista e independiente.

Consejos obreros. En lo económico: 1) La fábrica pertenece a los trabajadores. 2) El cuerpo supremo de control de la fábrica es el Consejo obrero, elegido por los trabajadores. 3) El Consejo obrero elegirá a su Comité supremo, que tendrá entre tres y seis miembros. 4) El Consejo resolverá los problemas derivados de contratos y despidos. 5) El Consejo tiene derecho a examinar los balances y decidir qué se hace con los beneficios. En lo político: 1) Elecciones libres y democráticas bajo el control de las Naciones Unidas. 2) La admisión de todos los partidos democráticos. 3) Libertad de prensa y de asociación. Actividad libre de los sindicatos. 4) Nueva parcelación de las tierras entre los campesinos. 5) Libertad a los presos políticos. 6) Eliminación de las diferencias de clase. 7) Reparación de las graves injusticias cometidas contra la Iglesia. 8) Disolución inmediata de la policía secreta. 9) Retirada inmediata de la policía soviética.

Las declaraciones las transcribimos de Dolores Ferrero Blanco, "La revolución húngara de 1956: el carácter político y la organización social”: Historia actual, n. ${ }^{\circ} 10$ (2006), pp. 99-113.

30 Claude Lefort, La complication. Retour sur le communisme, Fayard, Paris, 1999, passim.

31 Jean Paul Sartre, "Le fantôme de Staline", en Situations VII, Gallimard, Paris, 1965. Publicado originalmente en Les Temps Modernes, n. ${ }^{\text {os }} 129,130$ y 131(noviembre-diciembre 1956, enero 1957). 
comunistas franceses, que no hacen más que aumentar la cólera sartreana. Pero este primer gesto es moral. Sartre lo reconoce y lo concibe incompleto: hace falta un análisis político de los hechos acaecidos que les reintegre su inteligibilidad y permita comprender para poder condenar políticamente la matanza soviética. Pero no cualquiera puede comprender. Solo los que creen en el socialismo e integran el movimiento socialista están facultados para comprender y juzgar. Esto es así "porque es el movimiento del hombre en camino de hacerse" "32. Por tanto, si por un lado se denuncian las falsedades comunistas, presas de una ideología granítica, y se propone un análisis político laico, por el otro se resguarda la creencia en el futuro socialista de la humanidad como última ratio de todo juicio político emprendido: "Diremos, pues, para comenzar, que el comunismo nos parece, a pesar de todo, el único movimiento que todavía lleva en sí las posibilidades del socialismo"33. La indagación se detiene ante el umbral del ideal revolucionario; así lo confirma el riguroso estudio de Ian Birchall ${ }^{34}$. El autor trasluce el tono de la crítica sartreana: avance y freno, un entrevero forjado en la vacilación entre reformar el comunismo o revolucionarlo.

En lo que respecta al derrotero de la política estalinista, Sartre recupera los análisis de Isaac Deutscher (1907-1967) ${ }^{35}$ : el estalinismo, a pesar de su brutalidad policíaca, significó una opción legítima para la construcción del socialismo en la URSS a raíz de las condiciones singulares de Rusia en el momento de la Revolución y en su derrotero inmediatamente posterior: atraso económico y cultural, aislamiento internacional. El error de los dirigentes soviéticos fue aplicar sin excepción el modelo soviético de edificación socialista a todos los países del Este. En concreto: el no reconocimiento de la especificidad de las relaciones económico-sociales de Hungría es la causa estructural, por así decirlo, del descontento del pueblo húngaro, que dio pie al levantamiento de 1956. A este aspecto se le suma el aplastamiento de la nacionalidad húngara, provocada por la subordinación humillante de los dirigentes comunistas húngaros frente a las directivas que emite el Kremlin. Se trata de un exceso de centralismo, dirá Sartre, que desemboca en una opresión política. Que puede ser revocable si se aflojan los tornillos clavados durante el periodo estalinista. Para Sartre, la opresión de la URSS sobre Hungría es política y no económica. Por tanto, el sistema de relaciones es modificable, si se abandonan los presupuestos estalinistas dentro del horizonte socialista; ya que, en buen marxismo, si no hay contradicciones económicas, no hay problemas sistémicos. Y justamente, en el argumento sartreano las dificultades económicas se deben a yerros en la aplicación y la opresión política tuvo como causa la torpeza producto de la desconfianza. Errores y torpezas. Una serie de malentendidos parecen explicar la Revolución húngara.

Ahora bien, lo llamativo es que en la explicación sartreana también puede advertirse el reconocimiento de la radicalidad y la novedad de la sublevación. Sartre rechaza con fuerza el veredicto esgrimido por los comunistas acerca del significado contrarrevolucionario del levantamiento. En Hungría, los obreros fueron actores centrales de la insurrección. Los consejos obreros, que florecieron a lo largo del país, lo demuestran. Sartre no deja de destacar la importancia de los consejos como puntas

\footnotetext{
"Parce qu'il est le mouvement de l'homme en train de se faire". Ibid., p. 148.

"Nous dirons donc pour commencer que le communisme nous apparaît, malgré tout, comme le seul mouvement qui porte encore en lui les chances du socialisme". Ibid., p. 150.

Ian Birchall, Sartre et l'extrême gauche française, La Fabrique, Paris, 2011.

Isaac Deutscher, Stalin: un biografía politica, Era, México, 1965.
} 
de lanza de un auspicioso socialismo democrático, que define, es el hecho capital, el sentido profundo de la insurrección ${ }^{36}$. Pero, nuevamente, Sartre endereza el timón: la contradicción entre los consejos obreros y la burocracia comunista no es esencial, de fondo; por otra parte: "del 23 de octubre al 1 de noviembre, el deslizamiento hacia la derecha es innegable; la situación se deteriora" ${ }^{37}$. La burocracia no es una clase ${ }^{38}$, su dominación no se sustenta en la explotación; comete abusos, sí, detenta un poder incompatible con el socialismo, también; pero, a fin de cuentas, - como lo sostuvo León Trotsky (1879-1940), retomando la definición marxiana de la burocracia ofrecida en el 18 Brumario - es una excrecencia, una superestructura causada por el desarrollo contingente del socialismo en un país atrasado. Los consejos obreros instituidos por la insurrección húngara - a propósito: Sartre no habla de revolución, porque las revoluciones las impulsa una clase contra otra y si la burocracia no es una clase, solo queda lugar para levantamientos, protestas más o menos violentas, que pretenden abrir un sendero de reformas - perfilan un nuevo horizonte para el socialismo, que, sin embargo, es compatible con la tradición política inaugurada en octubre de 1917.

Ahora bien, lo que nos parece que explica las idas y vueltas, las maniobras intempestivas, es el persistente intento de salvaguardar el ideal de la revolución socialista moldeado por la gesta de octubre y la consecuente vigencia del modelo jacobino-bolchevique de transformación. El socialismo está encarnado en la URSS y en los países del Este, pero encarnado de un modo defectuoso, es una empresa averiada. En consecuencia, para Sartre - cuya postura se asemeja a la de Irme Nagy (1896-1958) y a la de Georg Lukács (1885-1971), ministro de Cultura del efímero nuevo gobierno, quienes buscaban encauzar la insurrección y frenar la invasión soviética- de lo que se trata es de corregir errores. En este caso, quedar preso de la política estalinista, cuando el proceso histórico reclamaba una superación de los añejos métodos de Stalin, azuzó el levantamiento y, lo que es peor, definió la interpretación del hecho y el modo de resolverlo. He allí el fantasma que azota al socialismo y le impide regenerarse.

Sartre es un singular reformista: en la URSS y en las democracias populares ya aconteció la revolución, solo restan reformas, sin duda profundas, que permitan reconciliar al socialismo con la libertad. Esta es la postura política sartreana durante las décadas de los cincuenta y sesenta, no importa cuán lejos o cerca se encuentre del Partido Comunista francés; luego de mayo del sesenta y ocho y de la invasión soviética a Checoslovaquia, Sartre modifica su postura, se aleja del sovietismo y concluye que "hay que abandonar el moralismo y la ilusión reformista: no se arreglará la máquina, es necesario que los pueblos se apoderen de ella y la arrojen a la basura" 39 . No obstante, este estilo peculiar de argumentación, que reconoce las taras del régimen soviético y las critica violentamente, pero que mantiene, al mismo tiempo, el punto de vista privilegiado para el intento de construcción socialista que allí se realiza, hizo que Sartre se convirtiera, por lo menos durante los años de la Revolución húngara, según Lefort, en:

\footnotetext{
Ibid., pp. 190-191.

"Du 23 octobre au $1^{\text {er }}$ novembre, le glissement à droite est indéniable; la situation se détériore". Ibid., p. 192. Ibid., p. 207.

Jean Paul Sartre, "El socialismo que venía del frío", en Situación XIX, Losada, Buenos Aires, 1973, p. 207.
} 
El único abogado del PC que se puede escuchar. Fajon, Stil, Duclos vociferan y sus mentiras son tan groseras que el militante no las escucha. Sartre, en cambio, quien se indigna frente a esas mentiras, ofrece a sus lectores comunistas, intelectuales, estudiantes, las razones de su permanencia en el partido ${ }^{40}$.

\subsection{Pluralismo y modernización}

Raymond Aron escribió un pequeño texto ${ }^{41}$ - una brochure - acerca de la Revolución húngara, a la que no duda en calificar como una revolución anti-totalitaria. Sin embargo, la revolución es pensada en el marco de los cambios de regímenes políticos teorizados por la ciencia y la sociología política ${ }^{42}$. Aron repasa las tres formas conocidas, en el siglo veinte, de quiebre del orden democrático ${ }^{43}$ : la llegada al poder de un partido autoritario por una vía legal; el golpe de estado; y las derrotas militares, vía invasión (Francia, 1940) o liberación (Europa oriental). Por el contrario, hasta el momento, dice Aron, ningún Estado autoritario había sido derrotado desde dentro por una revolución popular iniciada en la calle. Es el caso de Hungría, que recuerda las revoluciones europeas del siglo diecinueve: un movimiento popular que va de la calle al palacio de gobierno. Así, la Revolución húngara deja dos enseñanzas, aunque contradictorias. Por un lado, demuestra que el totalitarismo puede ser derrotado por un levantamiento popular - no obstante, Aron, al igual que Sartre y Arendt, destaca que el círculo del totalitarismo aún no se había cerrado en Hungría y por eso podían filtrarse con mayor facilidad que en la URSS, por ejemplo, los deseos de libertad-. Pero, por otro lado, un levantamiento popular al estilo decimonónico en plena guerra fría, o en la era de la guerra total, no es más que una bella ilusión. En este texto, Aron revela al unísono los dos senderos que trazaron sus reflexiones: la pasión por la libertad y el realismo político de raíz maquiaveliana ${ }^{44}$. La acción del pueblo húngaro - y su tragedia, digamos - lo conmueve, pero el realista apuesta más a las reformas anunciadas por Jruschov que a los efluvios libertarios de un pueblo en armas. Aunque también la clave de este doble movimiento puede hallarse en el nivel teórico.

Aron insiste en la incompatibilidad entre los regímenes europeos del Oeste y el Este; sin embargo, su tesis acerca del devenir de la sociedad industrial ${ }^{45}$ sostiene la posibilidad de una convergencia a nivel económico-social entre los dos sistemas, cuya discusión comenzaría a transitar por la eficiencia de los mecanismos económicos empleados en un contexto de sociabilización similar. Entonces, el antagonismo, sin duda fundamental, radicaría en los regímenes políticos, entendidos a partir de las

$40 \quad$ "Le seul avocat du P.C. qu'on puisse écouter. Fajon, Stil, Duclos vocifèrent et leurs mensonges sont si grossiers que le militant ne les écoute guère. Sartre, en revanche, qui s'indigne de ces mensonges, expose à ses lecteurs communistes, intellectuels, étudiants, les raisons qu'ils ont de rester dans le parti". Claude Lefort, "La méthode des intellectuels progressistes", en Éléments d'une critique de la bureaucratie, Gallimard, Paris, 1979, pp. 251252.

41 Raymond Aron, "Une Révolution antitotalitaire", en Penser la liberté, penser la démocratie, Gallimard, Paris, 2005. Publicado originalmente como prefacio a un texto que recopila testimonios acerca de la revolución editado por Melvin Lasky y François Bondy, La Révolution hongroise: histoire du soulèvement d'octobre, Plon, Paris, 1957.

42 Ibid., p. 400.

43 En este sentido, anticipa los posteriores análisis politológicos acerca de las causas del fin de la democracia y de su posible reequilibramiento en un contexto de crisis, como es el caso del texto clásico de Juan Linz, La quiebra de las democracias, Alianza, Madrid,1987.

44 Allí lo sitúa Serge Audier en su ensayo acerca del "momento maquiaveliano francés": Machiavel, conflit et liberté, Vrin, Paris, 2005, cap. 1.

45 Aron, "Dix-Huit leçons sur la société industrielle", en Penser la liberté, penser la démocratie, pp. 751-889. 
reglas de acceso al poder del Estado y del margen de libertad para oponerse y/u opinar acercar de él. En el Este europeo existen regímenes monopólicos de partido único y en el Oeste regímenes pluralistas, competitivos y multipartidistas. Dicho enfoque, sugiere Aron, seculariza la filosofía de la historia — vulgar, pero eficaz en el imaginario progresista de Occidente-, que pensaba el pasaje de la "democracia burguesa" al "socialismo soviético" como parte del movimiento progresivo de la historia. Ahora, los cambios de régimen pueden ser analizados a partir de los elementos que los constituyen y los diferencian de otros. Por eso, la demanda de elecciones libres y competitivas, la restauración del pluralismo político y social, la promoción de las libertades civiles y públicas, que fueron el cogollo de la insurrección, son irreconciliables con el régimen comunista imperante, cuyo núcleo es el monopolio irrestricto del poder. En la senda clásica de Montesquieu (1689-1755), Aron define los sucesos como un conflicto entre la libertad — que es siempre la misma- y el despotismo oriental.

Ahora bien, la oposición entre democracia y totalitarismo está atravesada por la confluencia que promueve el industrialismo, en cuanto sistema social sustentado en el continuo crecimiento económico y cuyo pilar de legitimación es el aumento del nivel de vida de la población. Por eso, Aron soslaya la cuestión de los consejos y del control obrero de la producción — o en otras palabras, el lema de Socialisme ou barbarie: revolución proletaria contra la burocracia-; le parecen una muestra de romanticismo revolucionario propio del siglo diecinueve, incapaz de dar cuenta de las exigencias organizativas de la era de las masas, cuya persistente demanda de aumento de nivel de vida requiere de grandes conglomerados industriales comandados por especialistas. En rigor, el rasgo proletario y socialista de la revolución es menoscabado en pos de afirmar que los acontecimientos revelan la posibilidad del encuentro, consolidado en Occidente, entre el pluralismo político y la modernidad industrial, más allá de la propiedad de los medios de producción.

En efecto, el menoscabo de la política socialista y democrática de los obreros húngaros desemboca en la implícita solución para la contradicción entre la libertad y el realismo: el reformismo de las elites. En el contexto de la Guerra Fría, con sus zonas de influencia defendidas militarmente, no hay lugar para entroncar la democracia con la emancipación; se trata, más bien, de propiciar la amalgama del industrialismo con un mínimo de libertades públicas; o sea, en el caso de los países caídos detrás de la cortina de hierro, introducir reformas liberales en los engranajes del poder. Aron no es demasiado optimista al respecto - los amagues de Jruschov tras el XX Congreso lo animaron moderadamente-; sin embargo, considera que no hay otra cosa que hacer. La Revolución húngara fue un llamado, un despertar frente a la ideología gauchiste que fusionaba democracia y sovietismo, pero su inviabilidad práctica resitúa la mirada en las elites comunistas confrontadas a las renovadas ínfulas de pueblos que aprendieron a rebelarse. En suma: la perspectiva aroniana permanece dentro de un estudio comparativo de las elites políticas en el cuadro de determinados regímenes, englobados, todos, en la modernidad industrial, cuya conclusión es más realista en sentido clásico (política de poder) que maquiaveliana - a pesar de la sugerente interpretación de Audier ${ }^{46}$ - , por lo menos para las naciones sovietizadas. Allí, con esa moldura conceptual, la Revolución húngara se reduce a un grito

46 Audier, Machiavel, conflit et liberté, passim. 
descarnado, que el análisis racional debe encauzar a fin de extraer las consecuencias - algo sombrías, es verdad - y los cursos posibles de acción:

La lección que debemos animarnos a sacar es clara: el interés común de los pueblos prisioneros y de Occidente es que la oposición al comunismo permanezca provisoriamente al interior del régimen. Puesto que Occidente no puede ni quiere intervenir, puesto que la Unión Soviética tiene los medios y la determinación necesaria para aplastar las revoluciones, la única perspectiva —al margen de la eventual evacuación simultánea de las dos partes de Europa por los ejércitos ruso y americano - es una transformación de la práctica comunista, en Rusia y en los países satélites ${ }^{47}$.

\subsection{Los consejos: una nueva forma de gobierno}

Hannah Arendt escribió Reflexiones sobre la revolución húngara en 1958, luego insertado como epílogo a la segunda edición en inglés de Los orígenes del totalitarismo $o^{48}$, a fin de inteligir el sentido de la revolución en el contexto general del totalitarismo de posguerra y de la nueva situación iniciada con la muerte de Stalin. La Revolución húngara repuso durante un breve lapso el sentido de la política: la libertad. Los insurrectos demandaban cosas tan obvias como la libertad de pensamiento y de acción, pero no se contentaron con reclamarla sino que la pusieron en práctica; para ello idearon, reabriendo el canal subterráneo que une a las revoluciones modernas, una inusitada forma política: los consejos. Sin embargo, Reflexiones sobre la revolución húngara ${ }^{49}$ no profundiza en la cuestión de los consejos como forma de gobierno, se limita a enumerar sus cualidades, debido a que la preocupación se enfoca en el derrotero de la empresa comunista tras la muerte de Stalin, el aplastamiento de la Revolución húngara y la conquista del poder por parte de Jruschov. No obstante, el texto está en diálogo abierto con el posterior ensayo sobre las revoluciones modernas: Reflexiones sobre la revolución húngara oficia de puente entre Los orígenes del totalitarismo ${ }^{50}$ y Sobre la revolución ${ }^{51}$. En este último hallamos una iluminadora reflexión acerca de la potencialidad de los consejos y en ese marco teórico debemos incluir el significado de "las llamas que iluminaron durante doce largos días el vasto paisaje del totalitarismo de posguerra"; la Revolución húngara "fue un verdadero acontecimiento, cuya envergadura no dependerá de la victoria o la derrota; su grandeza está asegurada por la tragedia que los hechos representaron" 52 .

47 "La leçon qu'il faut avoir le courage de tirer résolument est claire: il est de l'intérêt commun des peuples prisonniers et de l'Occident que l'opposition au communisme demeure provisoirement à l'intérieur du régime. Puisque l'Occident no peut ni ne veut intervenir, puisque l'Union soviétique a les moyens et la détermination nécessaires pour écraser les révolutions, la seule perspective —en dehors de l'éventuelle évacuation simultanée des deux parties de l'Europe par les armées russe et américaine - est une transformation de la pratique communiste, en Russie et dans les pays satellites". Aron, "Une Révolution antitotalitaire", p. 410.

48 En las subsiguientes ediciones el epílogo fue dejado de lado, las ediciones en castellano no lo incluyen en ningún caso.

49 Hannah Arendt, "Reflexiones sobre la revolución húngara", en Karl Marx y la tradición del pensamiento occidental, Encuentro, Madrid, 2007, pp. 67-120.

50 Hannah Arendt, Los origenes del totalitarismo, Alianza, Madrid, 2002.

51 Hannah Arendt, Sobre la revolución, Alianza, Madrid, 1988.

52 Arendt, "Reflexiones sobre la revolución húngara", p. 67. 
En efecto, Arendt sostiene en el capítulo final de Sobre la revolución que los consejos son la auténtica, y prácticamente única, escuela de la acción política en la desgraciadamente triunfante sociedad del consumo y de la labor. En ese capítulo, luego de ponderar la propuesta jeffersoniana del sistema de distritos, que hubiera permitido una revalorización del espíritu público de la revolución y lamentar su fracaso por la compresión del concepto de felicidad en términos de bienestar privado, se pasa a analizar la significación de los consejos, auténticos herederos de la república elemental jeffersoniana.

Arendt inicia su argumentación señalando la disputa a muerte entre los consejos y los partidos revolucionarios, es decir, el conflicto entre la acción libre y espontánea y la lógica de la representación, los programas cerrados y la creencia en la férrea ley de la necesidad histórica. La autora veía los sistemas de consejos en abierta contradicción con la ideas de Marx y Vladimir Lenin (1870-1924), quienes identificaban el poder con la posesión del monopolio estatal de la violencia. Los consejos no se proponían la toma del poder, como los partidos revolucionarios, sino la constitución de otro poder de carácter republicano y federativo. Por tanto, el problema era dónde residía la legitimidad, si en los partidos o en los consejos, ya que, como es evidente, la consigna de Lenin "todo el poder a los soviets" se transformó en la práctica en todo el poder al Partido. En este combate - entre la necesidad histórica y la libertad política-, que se da en el seno de todas las revoluciones populares (Arendt las enumera $^{53}$ ), hay una excepción: Hungría,1956. Mientras las revoluciones anteriores - con la parcial excepción de la Comuna de París, la más cercana, en su "espíritu", a la húngara - se realizaron bajo el prisma modélico de la Revolución francesa: vanguardias políticas que aceptan, e incluso alientan, la formación de los consejos, para luego, invariablemente, aplastarlos o neutralizarlos, una vez consolidado su poder en el Estado y la preeminencia de su visión acerca del curso que debe tomar la revolución; en Hungría, por el contrario, debido a la experiencia concreta de una dominación total ejercida por un Partido de ideología monolítica, la revolución se apartó del modelo francés y se abrió paso hacia la fundación de la libertad: "Ninguna revolución ha resuelto nunca la 'cuestión social', ni ha liberado al hombre de las exigencias de la necesidad, pero todas ellas, a excepción de la húngara de 1956, han seguido el ejemplo de la Revolución Francesa" ${ }^{54}$.

Ahora bien, si la Revolución húngara se singulariza en relación a las otras revoluciones del siglo veinte por la inexistencia de partidos representativos capaces de unificar a fuerza de propaganda ideológica al pueblo - fusión que, por otra parte, socava la libre acción política que se define por la pluralidad-, ¿cómo explicar que en las revoluciones permanezca la demanda por el control obrero de la producción? O sea, la imbricación, que surge de la experiencia proletaria, entre libertades públicas y emancipación del trabajo asalariado. En efecto, si por un lado la constitución de los consejos como órganos permanentes, y no meramente provisorios, de la república renueva la luminosidad de lo público, por el otro la insistencia de los trabajadores, quienes mayoritariamente conforman e integran los consejos, en el control de la producción y la administración de las fábricas, pone en un terreno resbaladizo la argumentación arendtiana. Así lo sugiere Renato Ribeiro, quien apunta que Arendt

53 La Comuna de París de 1871, las Revoluciones rusas de 1905 y 1917, la alemana de 1918 y la húngara de 1956. Arendt, Sobre la revolución, p. 105.

54 Ibid., p. 112. 
nunca define el sentido de los consejos, ya que "si trataran todo lo que pertenece a lo social serían demasiados franceses, y si se restringieran a las cuestiones políticas estrictas tendrían poco que hacer" ${ }^{55}$. En efecto, Arendt considera a los consejos de fábrica como sindicatos económicos, que se limitaron a reemplazar a los sindicatos comunistas, quienes servían de correa de transmisión descendente entre la cúspide del poder y los trabajadores, pero ¿qué tipo de sindicatos son aquellos que se proponen la administración y el control de la producción? Arendt esquiva la respuesta porque sigue enfocada en mostrar el lazo entre economía-productiva, reproducción de la vida y necesidad. Así, la insistencia en la democratización de las relaciones de producción hubiese desembocado en los típicos problemas técnicos de la producción, que indefectiblemente requieren de expertos y por ende de la división entre dirigentes y ejecutantes. División que es, por definición, no política. En efecto, la constatación, el golpe de realidad o la certera enseñanza de la antigua Grecia: la vida económica, regida por la necesidad, que produce amos y esclavos, hubiera puesto a los revolucionarios húngaros en la encrucijada que obliga a elegir entre la libertad política, dejando la dirección de la producción económica a cargo de expertos, o ideologizar la economía productiva causando la ruina de lo público sin por eso resolver el problema del nivel de vida.

En suma, no se trata de repetir la obvia crítica a la supuestamente rígida distinción arendtiana entre lo político y lo económico-social —precisada, contra las acusaciones de conservadurismo, luminosamente por Étienne Tassin: "la distinción arendtiana apunta a prevenir la contaminación de la política por el juego de fuerzas sociales que hacen de ella un simple medio al servicio de éstas; y recusa, al mismo tiempo, la reducción de lo político a lo estatal" 56 -; más bien, se trata, de iluminar una zona pantanosa del pensar arendtiano: el cruce entre el resplandor de lo público y la tradición socialista de la emancipación del trabajo. La Revolución húngara es un suceso crucial para abordar ese vínculo, a pesar de que Arendt, acaso paradójicamente, teniendo en cuenta su crítica de la representación y su aversión por la lógica capitalista, tiende a regatearlo, acotando, así, la politicidad de lo político.

\section{Socialisme ou Barbarie: acuerdos y desacuerdos}

El grupo político/intelectual Socialisme ou Barbarie ${ }^{57}$ hizo del combate contra el comunismo soviético el eje de su preocupación intelectual y la médula de su apuesta política. Disconformes con la explicación trotskista acerca de la "revolución traicionada", los miembros del grupo intentaron renovar el análisis marxista de la sociedad frente a la inusitada formación social que se forjó en Rusia y, más adelante, en Europa oriental. El estalinismo consolidó un novedoso esquema de relaciones de producción ${ }^{58}$ — cuyo modo de producción correspondiente era el capitalismo de Estado - y por ende un nuevo tipo de oposición social. Bajo la férula estaliniana

55 Renato Ribeiro, La última razón de los reyes, Colihue, Buenos Aires, 1998, p. 103. En la misma senda crítica, véase Eduardo Grüner, Las formas de la espada, Colihue, Buenos Aires, 1997, cap. 3.

56 Étienne Tassin, Le trésor perdu. Hannah Arendt l'intelligence de l'action politique, Paris, Payot, 1999, p. 23.

57 Empleamos la noción de grupo político/intelectual en sentido lato, incluyendo la dimensión teórica y la publicación de la revista. Para una discusión acerca de esta doble valencia del colectivo véase Raflin, Socialisme ou barbarie: du vrai communisme à la radicalite, passim.

58 Cornelius Castoriadis, "Les rapports de production en Russie", en La société bureaucratique, Christian Bourgois, Paris, 1990. Publicado originalmente en Socialisme ou barbarie, n. ${ }^{\circ} 2$ (mayo 1949), pp. 205-282. 
el proletariado era explotado colectivamente por una burocracia, elevada a clase dominante por un régimen sustentado en la ideología y el terror. Además, la tendencia hacia la concentración y verticalización económica inscripta en la dinámica del capitalismo fue llevada hacia el extremo en el capitalismo burocrático de Estado, con su economía planificada y dirigida centralizadamente. Como Aron - aunque con valoraciones divergentes - Socialisme ou Barbarie destacaba la lógica convergente de los sistemas de explotación regidos por la racionalidad industrial. No obstante, el rigor del centralismo aplicado en los países sovietizados exigía, por un lado, coacciones extra-económicas - el terror, de forma saliente-, pero, por el otro lado, volvía más vulnerable el sistema, ya que el proletariado podía apropiarse con mayor facilidad de una industria colectivizada. El inmenso poder de la burocracia — dirigir una industria concentrada y apropiarse de la plusvalía social para reproducirse como clase - tenía, en el fondo, pies de barro. Lo demostró, en primer lugar y de manera criminal, las periódicas purgas contra la burocracia que desataba Stalin. La burocracia es un aparato colectivo de apropiación, que se recrea y expande a partir del sacrificio individual de sus miembros y de su estricta subordinación al Partido. Es una clase porque se diferencia colectivamente del proletariado, pero su ser existe a través de la integración en el aparato del Estado y en la sociabilización totalitaria que ofrece el Partido ${ }^{59}$. La burocracia, en contraste con la burguesía, no es una clase diferenciada, con campos de autonomía relativa, ergo el proletariado puede derrumbarla con una fulgurante acción revolucionaria: en el reino tiránico de la dominación burocrática, la revolución está siempre a la orden del día (acaso se trate de un retazo del añejo trotskismo de los miembros del grupo, pero es el pilar de su imaginario revolucionario).

En rigor, el análisis marxista de la "sociedad burocrática" desemboca en el lema político del grupo: revolución proletaria versus burocracia. Contra la enorme mayoría de las corrientes marxistas de la época, que situaban la revolución en la zona capitalista y se limitaban a pedir reformas para los países del "socialismo real" —o a lo sumo una revolución política, imaginada en su momento por Trotsky- porque, en efecto, en esas sociedades la revolución ya sucedió, Socialisme ou Barbarie ubicó las "contradicciones revolucionarias" más explosivas en las sociedades del Este europeo. El fallo crucial del pensamiento marxista hegemónico fue confundir la nacionalización de los medios de producción con el socialismo (desatino que está en la base del rechazo sartreano de considerar como una clase a la burocracia). ¿El resultado de la confusión? Soslayar el rasgo de clase de la burocracia y mezclar el socialismo con la planificación de la economía y el aumento constante de la producción. Pero el socialismo, en verdad, es la superación de la explotación a través de la gestión colectiva de la producción, y la propia experiencia proletaria inventó las instituciones para gestionarla colectivamente: los consejos obreros. Incluso dicha gestión desborda hacia el conjunto de la sociedad, porque el socialismo supone el rol dirigente de los consejos obreros en la vida social.

Socialisme ou barbarie asumirá una postura consejista y de autonomía obrera - aunque dentro de ella el lugar de la dirección proletaria será objeto de intricadas polémicas - crítica de todas las formaciones de izquierda de la época - principalmente de los partidos comunistas, fuerza dominante en el movimiento

59 Claude Lefort, "Le totalitarisme sans Staline”, en Éléments d'une critique de la bureaucratie, pp. 155-235. Publicado originalmente en Socialisme ou barbarie, n. ${ }^{\circ} 14$ (julio-septiembre, 1956), pp. 320-388. 
obrero- y prestará suma atención al desarrollo de los acontecimientos dentro del orbe comunista. El estallido de la Revolución húngara vino a confirmar sus análisis teóricos y sus apuestas políticas. El entusiasmo es manifiesto: la Revolución húngara tiene un alcance universal y señala el rumbo de la lucha proletaria por el socialismo tanto en el Este como en el Oeste ${ }^{60}$.

Sin embargo, la Revolución húngara solo es inteligible dentro del universo que fomenta la dominación totalitaria ${ }^{61}$. El totalitarismo, al barrer con cualquier posibilidad de autonomía social o individual, ilumina, por carencia, la solidaridad entre la libertad política y la igualdad social. Ya no es factible la eficaz operación ideológica por la cual se clama por la libertad cuando en realidad se busca garantizar la libertad burguesa. Muerto el liberalismo, la libertad se desprende de su carácter fetichista. Por eso, bajo el totalitarismo se torna nodal el problema de la fundación de la libertad; fundación que incluye la radical abolición de la explotación. La experiencia de la dominación hace que la clase obrera incorpore la problemática de la libertad política; véanse las proclamas de los consejos obreros. No obstante, lo que define la vigorosidad y madurez del movimiento de los consejos es la reivindicación del control de la producción, debido a que, y es la cuestión crucial para Socialisme ou barbarie, solo modificando la relación tiránica entre directores y ejecutantes, y no meramente cambiando la propiedad jurídica de los medios de producción, es posible transformar las relaciones de producción y sociabilizar la sociedad. Pero tal gesto no anula la dilucidación acerca de que los consejos se proponen como otro poder de significación universal, es decir, que su modo autónomo de organización bosqueja una suerte de República de los consejos: otra forma de Gobierno. Los obreros húngaros plasman un peculiar modo de vivir en común, que impacta de lleno en el sistema totalitario, en el carácter propiamente político del totalitarismo: el Partido único con una ideología omnicomprensiva que oculta cualquier división social. El proletariado reclama elecciones libres, libertad de expresión y, sobre todo, la libertad de organizarse.

Se trata, entonces, de una revolución anti-totalitaria, que, por el revés, arroja luz sobre la imbricación entre democracia y socialismo. Los consejos pretenden autogobernarse. Rechazan, en especial, la dominación: las directivas del Partido, las exigencias del plan económico. Critican la jerarquía. Pero esa búsqueda de conformación de un espacio igualitario de no-dominación y autogobierno incluye en sus pliegos, y tenía que incluirlo porque eran trabajadores explotados los que se auto-organizaban, una regulación democrática de la producción. Es como si pidieran que las libertades públicas se extendieran al terreno de las relaciones de producción. Y esa extensión porta el nombre de socialismo.

Ahora bien, Castoriadis, en la conclusión de uno de sus artículos sobre Hungría, intenta extraer consecuencias programáticas de la Revolución húngara: "nuestra tarea es hoy, en primer lugar y ante todo, propagar el programa de la Revolución húngara y ayudar al proletariado francés en su lucha contra su propia burocracia, indisociable de su lucha contra la explotación capitalista" ${ }^{2}$.

\footnotetext{
60 La revista dedicó varios números — el 20, 21, 22 y 24- al estudio de los acontecimientos. En el n. ${ }^{\text {o }} 20$ (1956) Lefort publicó "L'insurrection hongroise", pp. 85-116.

${ }_{61}$ En adelante seguimos "L'insurrection hongroise" de Lefort.

62 "Notre tâche est d'abord tout aujourd'hui de propager le programme de la révolution hongroise, d'aider le prolétariat français dans sa lutte contre sa propre bureaucratie, indissociable de sa lutte contre l'exploitation capita-
} 
Las conclusiones programáticas de Castoriadis deben inscribirse en la polémica, que periódicamente se renovaba dentro del grupo, entre la necesidad de una dirección revolucionaria y la autonomía obrera como incubación del socialismo. ¿Eran compatibles la dirección y la autonomía? Castoriadis consideraba que sí, Lefort dudaba y se inclinaba por la negativa. Ambos se trenzaron en dos polémicas abiertas, respectivamente, en 1952 y en 1958. La última de ellas significó el alejamiento definitivo de Lefort de Socialisme ou barbarie ${ }^{63}$. Vamos a repasarlas brevemente a fin de observar cómo la visión "autonomista" de las luchas obreras defendida por Lefort se entronca con su interpretación de la Revolución húngara y traza un sendero que lleva a la noción de "democracia salvaje".

Como apuntamos, la divergencia se escenificaba alrededor de la posibilidad de construir un partido revolucionario, teniendo presente la degeneración burocrática, que había sido una constante en todas las organizaciones socialistas del movimiento obrero. Para Castoriadis, era posible evitar la deriva burocrática si se hacía una inteligente lectura de la experiencia histórica acumulada, se mantenía el temperamento revolucionario de los militantes, la libre discusión de ideas y el control democrático de las masas. Por otra parte, la conformación de una dirección revolucionaria era indispensable para llevar a buen puerto la lucha por el socialismo, y la propia existencia del grupo demostraba la necesidad de la misma: porque cómo se pensaban los miembros de Socialisme ou barbarie sino como un embrión de partido revolucionario. Este hecho justificaba la existencia del grupo y no la escritura intelectual; en consecuencia, renunciar al intento de construir el partido de la revolución por miedo a su posible degeneración burocrática significaba un abandono de la política y una elección por guarecerse, como almas bellas de la revolución, en el campo del debate de ideas. Lefort va a sostener, por el contrario, que de una vez por todas había que emancipar la política proletaria del fetichismo del partido revolucionario. El proletariado debe llevar adelante su combate por el socialismo de forma autónoma, con sus propias organizaciones de clase. La revolución, si se produce, será gracias a la experiencia proletaria y no como resultado de la dirección política de un partido de vanguardia. Para Lefort, todo grupo conformado de manera separada de la clase acabará ejerciendo una dominación sobre los trabajadores, es decir, tendrá un comportamiento burocrático. El fetichismo partidocrático impidió a Trotsky advertir "a tiempo" el significado del estalinismo. La creencia en la racionalidad histórica del partido del proletariado lo desarmó políticamente y preparó el triunfo de Stalin quien controlaba el aparato partidario; Trotsky estaba vencido desde el plano intelectual antes de la consumación de su derrota política ${ }^{64}$. Lefort observa que Socialisme ou barbarie se encamina a ser "el Trotsky de Trotsky"; o sea: a recomenzar la repetitiva historia de los auténticos representantes del proletariado, los nuevos custodios y promotores de la verdad histórica.

La polémica tiene un inconfundible sabor marxista, en ella resuenan los ecos de la añeja disputa entre Lenin y Rosa Luxemburg (1871-1919). Los dos autores franceses

liste". Cornelius Castoriadis, "La révolution prolétarienne contre la bureaucratie", en La société bureaucratique, Christian Bourgois, Paris, 1990, p. 406.

63 Los textos principales que recogen la controversia son: Claude Lefort, "Le próletariat et sa direction" y "Organisation et Parti”, en Éléments d'une critique de la bureaucratie, pp. 59-70; pp. 98-113 ; Cornelius Castoriadis, "El partido revolucionario" y "La dirección proletaria" (que incluye como colofón un resumen de los debates suscitados por el texto), en La experiencia del movimiento obrer, vol. 1, ¿Cómo luchar?, Tusquets, Barcelona, 1979 , pp. 103-143

64 Claude Lefort, “La contradiction de Trotski”, en Éléments d'une critique de la bureaucratie, pp. 33-58. 
la tenían muy presente, ya que ambos, en algún sentido, jugaban a radicalizar las posturas de los contrincantes evocados: Castoriadis pretendía ser un leninista más consecuente que el propio Lenin y Lefort un luxemburguista que extrema el obrerismo anti-comité central de Rosa. Sea. Sin embargo, lo que despierta nuestra curiosidad es el procedimiento intelectual de Lefort: hay que romper con la ilusión de la URSS como la patria del socialismo, con la tesis trotskista del Estado obrero degenerado para conceptualizar el régimen totalitario de Stalin, con el fetichismo del partido, con el vanguardismo, para que se produzca el encuentro histórico entre el proletariado y la revolución. El levantamiento húngaro en noviembre de 1956 revela que esa confluencia es factible: la autonomía obrera y el espontaneísmo auto-instituyente movilizado en la insurrección avizoran la posibilidad de otra constelación democrática y emancipadora. Las rupturas moldean el itinerario lefortiano; no obstante, la Revolución húngara seguirá ocupando un lugar sustancial cuando nuestro autor, a mediados de la década de los setenta piense el advenimiento de la democracia moderna.

\section{Veinte años después}

Al cumplirse dos décadas del acontecimiento húngaro, y munido de la contraposición entre revolución democrática y dominación totalitaria, Lefort escruta nuevamente el hecho en dos breves ensayos ${ }^{65}$. Los textos plasman rápidamente una primera conclusión: la Revolución húngara delineó una forma de sociedad democrática radical. Lefort destaca la imbricación entre los rasgos antiburocráticos y anticapitalistas de la insurrección y la puesta en escena del pluralismo y la división como condiciones fundantes de la libertad. La revolución desmontó la idea de un buen poder que reconcilie a toda la sociedad. Y este último aspecto es el que se destaca en estos textos. Si el intelectual marxista de los cincuenta hacía hincapié en el control obrero de la producción, el teórico-político de los años setenta señala la desconfianza de los insurrectos respecto al poder comunista, que garantizaba una existencia sin conflictos —orgánica: el pueblo-uno_- recostada en la indistinción entre Estado y sociedad y en la Historia como garante explicativo o sentido cristalizado que tornaba ociosa la tarea de interpretar la realidad. Las acciones del pueblo húngaro minaron las certezas totalitarias del poder comunista - los obreros levantándose contra el "Estado obrero" - y, en este sentido, la Revolución húngara debe colocarse dentro de la constelación de la revolución democrática: incertidumbre, heterogeneidad, invención y poder descorporizado. Ahora bien, la Revolución húngara no solo demuestra la naturaleza de la contraposición entre democracia y totalitarismo, sino que perfila las acciones de transformación en las sociedades modernas tout court. En efecto, como en "La insurrección húngara", en estos ensayos Lefort vuelve a ponderar el alcance universal de la revolución magiar; por eso sorprende que Bernard Flynn no haga alusión a esta constelación de reflexiones y se limite a comentar la interpretación de Lefort de las clásicas revoluciones francesa y soviética, aunque asombra menos si tenemos en cuenta que Flynn ubica el acontecimiento húngaro

\footnotetext{
65 Claude Lefort, "Hongrie 1956. Un révélateur historique" y "La première révolution antitotalitaire", en Le temps présent. Écrits 1945-2005, pp. 261-265; pp. 301-308.
} 
dentro de la crítica lefortiana al totalitarismo, obliterando, de esta manera, cualquier contrapunto con la democracia realmente instituida en Occidente ${ }^{66}$.

Dos aspectos colorean la dimensión universalizante del acontecimiento, más allá de su enraizamiento específico en las contradicciones de las sociedades sovietizadas: por un lado la crítica, implícita pero vigorosa, a la noción clásica de revolución como punto sublime de la historia que prometía acabar con los conflictos que desgarran a la sociedad produciendo una reconciliación global. La insurrección húngara abrió una brecha para que se cuele otra noción de revolución: heterogénea, plural, sin contradicciones fundamentales, sin principio ni fin; y, por el revés de la trama, deshizo la identificación de la revolución con el totalitarismo — correlato pergeñado por la crítica liberal, que Lefort impugna ${ }^{67}$ - y logró imbricarla con la democracia. Por el otro lado, la Revolución húngara ensayó una crítica democrática radical a toda forma de oligarquización del poder. Lefort encomia los rasgos anticapitalistas y antiburocráticos y los empalma con la preocupación de los insurrectos por definir derechos, no por un afán formalista, sino para establecer los alcances autónomos de cada campo de actividad. Pero además, el espíritu democrático que impulsó las acciones permitió imaginar una sociedad sustentada en diversos principios de autoridad. La ponderación de la federalización del poder, de un principio de autoridad diverso y descentralizado, acerca a Lefort al planteo arendtiano; sin embargo, pareciera ser que el significado republicano de la Revolución húngara solo cobra pleno sentido si comprendemos la institución del espacio público como una democratización radical de las relaciones sociales. Y bien, consideramos que es este - sea en clave socialista o en clave democrática anti-totalitaria- el punto neurálgico de la interpretación lefortiana, cuya consecuencia es el cruce - insinuado dramáticamente en Hungría - anticapitalista y antiburocrático de la democracia y la emancipación.

\section{Por una teoría libertaria de la democracia}

Hungría 1956 es un revelador histórico, pero no solo por su riqueza histórico-política sino también porque permite despuntar un conjunto de debates teórico-políticos alrededor, por lo menos, de dos conceptos decisivos: revolución y democracia. Para comenzar, y de acuerdo a nuestro encuadre, contrapongamos la perspectiva de Lefort con las de Sartre y Castoriadis, por un lado, y Aron y Arendt, por el otro.

A Sartre y a Castoriadis - aunque mucho más cerca del segundo que del primero, por las razones que ya vimos-, Lefort les disputa la noción de revolución. El alejamiento del ideal revolucionario, en cuanto praxis que regeneraría la totalidad de la historia, implica la crítica del marxismo reformista enarbolado por Sartre y del autonomismo alentado por Castoriadis, quien creyó hallar el contenido del socialismo y luego la posibilidad de una auto-institución permanente de la sociedad, tomando, también, como caso testigo lo sucedido en Hungría ${ }^{68}$. En ambos se configura la ilusión de una sociedad transparente - el grupo en fusión sartreano y

\footnotetext{
66 Flynn, Lefort y lo político, caps. 6 y 10.

${ }_{67}$ Claude Lefort, "La question de la révolution", en Le temps présent. Écrits 1945-2005, pp. 267-273.

68 Ver Cornelius Castoriadis, "La source hongroise", en Le contenu du socialisme, 10/18, Paris, 1979, pp. $367-412$.
} 
la auto-institución de Castoriadis ${ }^{69}$-, sin rugosidad, moldeable; no obstante, dicha ilusión revolucionaria prepara un revés turbador: la legitimación filosófico-política de un poder omnímodo. Entonces, la crítica del totalitarismo debe alcanzar la noción moderna de revolución, cuyo inquietante objetivo es el fin de la opacidad. Ahora bien, lo destacable, como venimos insistiendo, es menos la crítica en cuestión que el intento lefortiano por entroncar la temporalidad política de la transformación revolucionaria con lo democrático-político ${ }^{70}$. En efecto, Lefort — creemos que a partir de su lectura persistente de la Revolución húngara - redirecciona la herencia política de la revolución hacia el concepto tocquevilliano de revolución democrática. La chispa de esa imbricación enciende el rasgo salvaje de la democracia.

Pues bien, el nuevo sendero - anudamiento entre democracia y revolucióndispara la segunda polémica: contra Aron y Arendt. El pluralismo que emana de la Revolución húngara no se asemeja al pluralismo oligárquico de las elites políticas de Occidente; Lefort, a diferencia de Aron, se interesa por el encuentro entre las libertades públicas y la democratización del poder, cuya materialización, en Hungría, fueron los consejos revolucionarios y obreros. Incluso, nos aventuramos a sugerir que los consejos revelan la forma institucional de la democracia salvaje, imaginada teóricamente por nuestro autor. Por otra parte, la radicalidad de lo democráticopolítico también desborda el republicanismo consejista arendtiano. Para Lefort, las distinciones elaboradas por Arendt nacen de la obliteración del acontecimiento democrático. En rigor, la autora alemana, fascinada por el fenómeno revolucionario (de la Revolución americana a la insurrección húngara), por la centralidad que posee el comienzo, clave en lo político-arendtiano, disocia - illamativamente? - este fenómeno del advenimiento de la democracia. En Arendt no hay una preocupación teórico-política por la democracia, siendo, para Lefort, indisociable la modernidad de la revolución de la modernidad de la democracia ${ }^{71}$.

El anudamiento de la revolución y la democracia ilustra el rasgo esencial del pensamiento lefortiano acerca de lo político: la democracia salvaje ${ }^{72}$. Pero, a su vez, permite intentar una interpretación — en la senda de Miguel Abensour ${ }^{73}$ - de la democracia divergente respecto al institucionalismo liberal; o sea, a través del anudamiento, iluminar la reversibilidad entre democracia y emancipación.

${ }^{69}$ Es cierto que, en el caso de Castoriadis, y teniendo muy en cuenta los vericuetos complejos de su trayectoria teórico-política y militante - repasada exhaustivamente por Alfonso Ibañez, "Castoriadis o el proyecto de autonomía democrática": Areté: Revista de filosofia, vol. 16, n. ${ }^{\circ} 2$ (2004), pp. 207-241-, podemos matizar estas afirmaciones. En efecto, el proyecto de autonomía democrática pergeñado por Castoriadis es afín a la noción de democracia salvaje; de hecho, Ibañez moviliza la idea de una democracia libertaria surgiendo del pensar de Castoriadis, tal como nosotros la encontramos en Lefort; sin embargo, en este artículo nos ceñimos a la lectura lefortiana del derrotero de Castoriadis (véase Le temps présent, pp. 240-241). La pertinencia de dichos juicios, acaso algo forzados con la intención de producir un efecto de diferenciación a sabiendas de la afinidad entre ambas obras, es una cuestión sin duda muy interesante, pero escapa a los objetivos de este artículo.

70 Tomamos esta noción de Martín Plot, quien la define, en sentido lefortiano, como "la forma de lo social". No obstante, para nosotros, a diferencia de Plot, esa noción permite explorar una convergencia entre la "revolución democrática y las "revoluciones sociales" del siglo veinte. Plot, La carne de lo social, p. 11.

71 Claude Lefort, "Hannah Arendt et la question du politique", en Essais sur le politique, Seuil, Paris, 1986, pp. 64-78.

72 Noción que remite a la ontología salvaje de raíz merleau-pontyana y supone la apertura hacia un comienzo desligado de todo principio de autoridad; rebasando el orden instituido, la democracia salvaje es la indeterminación misma del ser político; lo salvaje es el indócil desafío a la domesticación institucional de la democracia. Véase Abensour, "Démocratie sauvage et principe d'anarchie", en Pour une philosophie politique critique, pp. 319-348.

73 Ibidem. 
Lefort, en el ensayo en que se interroga por la permanencia de lo teológicopolítico ${ }^{74}$, sintetiza su lectura de la modernidad y el sitio nodal que ocupan en ella la revolución y la democracia. El advenimiento de la democracia moderna supone una nueva configuración del lugar del poder. Los principios generadores de la institución de lo social y el modo en que la sociedad se representa a sí misma se modifican categóricamente. Con la democracia la originaria división social sale a la luz suscitando la legítima convivencia del poder y el conflicto. Y aunque la modernidad política construye figuras identitarias (el Pueblo, la Nación, la Patria, el Estado) para paliar el abismo de la división y el conflicto, no logra jamás darle un cuerpo a la sociedad y un lugar positivo, plenamente visible, al poder. La cercanía de estas figuras modernas con el mundo de lo religioso no deben confundirse con una nueva transposición de lo religioso en lo político, porque esta creencia nos ocultaría la novedad de la ruptura revolucionaria que emerge con la democracia, ruptura que se paga con una ambigüedad constitutiva: la infranqueable atracción por las seguridades del Uno y la inerradicable expansión de la división y el conflicto. Esa es la tragedia de la condición moderna. Lefort nos invita a aceptarla en lugar de fantasear con una restauración de la teología-política o con una resurrección del Deus mortalis. De esta manera, la democracia se confunde con lo inacabado, con un tiempo enrarecido y paradójicamente aupado en el cambio, que Lefort sintetizará con la noción de incertidumbre democrática, y que nosotros mentamos, a partir de los efectos de la Revolución húngara, como la imbricación entre la revolución y la democracia. La imbricación descubre la ontología salvaje de la democracia, o sea, su ligazón con la siempre irredenta cuestión de la emancipación.

En este sentido, Miguel Abensour propone una sugerente constelación. Esta busca ligar lo político a la cuestión de la emancipación sosteniendo, sin soltar ninguna, tanto la crítica del totalitarismo como la crítica del universalismo liberal. Así, Abensour sitúa a Lefort en un horizonte de discusión (distinto al que se abre polemizando con la ética discursiva habermarsiana o con las aporías de la legitimidad democrática) enraizado en los complejos legados libertarios - desde Etienne de la Boétie (1530-1563) hasta Pierre Clastres (1934-1977) — que se anima a pensar la democracia como el semblante político de la emancipación humana, es decir: como democracia salvaje. En suma, nuestra lectura de las relaciones entre la democracia y la revolución en el marco de las vicisitudes de la trayectoria lefortiana, a partir de los persistentes efectos de la insurrección húngara, buscó situar, como dijimos, una perspectiva teórico-política que, sin verse obligada a renegar de las revoluciones sociales modernas como billete de entrada a una filosofía política de la democracia, pretende religar y tensar el emblema de la revolución democrática con la acción política emancipadora de la revolución (húngara) en cuanto potencia capaz de suscitar una continua transformación de la sociedad.

En fin, consideramos que la revolución húngara se le reveló a Lefort como un efímero bosquejo de la "democracia salvaje", que jamás podrá reconciliarse plenamente con lo real-institucional, aunque la persistencia de su memoria socava, viejo topo irredento, la tendencia oligárquica del poder. Poder que a menudo olvida su enraizamiento en la división social, fuente de la puesta en escena democrática, cuyo rasgo emancipador afloró en Hungría entre el 23 de octubre y el 4 de noviembre de 1956.

74 Claude Lefort, "Permanence du théologico-politique?", en Essais sur le politique, pp. 275-329. 


\section{Referencias bibliográficas}

Abensour, Miguel, Pour une philosophie politique critique, Sens \& Tonka, Paris, 2009.

—, "Démocratie sauvage et principe d'anarchie", en Pour une philosophie politique critique, Sens \& Tonka, Paris, 2009.

Aldcroft, Derek, Historia de la economía europea 1914-2000, Crítica, Barcelona, 2003.

Arendt, Hannah, Sobre la revolución, Alianza, Madrid, 1988.

—, Los orígenes del totalitarismo, Alianza, Madrid, 2002.

—, "Reflexiones sobre la revolución húngara", en Karl Marx y la tradición del pensamiento occidental, Encuentro, Madrid, 2007.

Aron, Raymond, "Une Révolution antitotalitaire”, en Penser la liberté, penser la démocratie, Gallimard, Paris, 2005.

Audier, Serge, Machiavel, conflit et liberté, Vrin, Paris, 2005.

Birchall, Ian, Sartre et l'extrême gauche française, La Fabrique, Paris, 2011.

Castoriadis, Cornelius, "El partido revolucionario", en La experiencia del movimiento obrero, vol. 1, ¿Cómo luchar?, Tusquets, Barcelona, 1979.

—, "La dirección proletaria", en La experiencia del movimiento obrero, vol. 1, ¿Cómo luchar?, Tusquets, Barcelona, 1979.

_- "La source hongroise", en Le contenu du socialisme, 10/18, Paris, 1979.

—, "Les rapports de production en Russie", en La société bureaucratique, Christian Bourgois, Paris, 1990.

—, "La révolution prolétarienne contre la bureaucratie", en La société bureaucratique, Christian Bourgois, Paris, 1990.

Caute, David, Les compagnons de route 1917-1968, Lafont, Paris, 1975.

Deutscher, Isaac, Stalin: un biografía política, Era, México, 1965.

Fejtö, François, La tragédie hongroise, Pierre Horay, Paris, 1956.

_, Budapest 1956: la révolution hongroise, René Julliard, Paris, 1966.

Ferrero Blanco, Dolores, "La revolución húngara de 1956: el carácter político y la organización social": Historia actual, n. ${ }^{\circ} 10$ (2006), pp. 99-113.

Flinn, Bernard, Lefort y lo político, Prometeo, Buenos Aires, 2008.

Furet, François, El pasado de una ilusión. Ensayo sobre la idea comunista en el siglo XX, FCE, México, 1995.

Grüner, Eduardo, Las formas de la espada, Colihue, Buenos Aires, 1997.

Heller, Agnes y Feher, Ferenc, Análisis de la revolución húngara de 1956, Hacer, Barcelona, 1983.

Hobsbawm, Eric, Historia del siglo XX, Buenos Aires, Crítica, 1998.

Ibañez, Alfonso, "Castoriadis o el proyecto de autonomía democrática": Areté: Revista de filosofia, vol. 16, n. ${ }^{\circ} 2$ (2004), pp. 207-241.

Judt, Tony, Postguerra. Una historia de Europa desde 1945, Madrid, Taurus, 2006.

Kecskeméti, Paul, The Unexpected Revolution. Social Forces in the Hungarian Uprising, Stanford University Press, Stanford, 1961.

Kleja'nsky, Sarolta, "Le parti communiste français et l'intervention soviétique en Hongrie", en Le parti communiste français et l'année 1956, Actes des journées d'étude organisées par les archives départementales de la Seine-Saint Denis, Mémoire en ligne, 2007. Disponible en: http://www.gabrielperi.fr/assets/files/pdf/Le_PCF_et_l_annee_1956.pdf (septiembre 2016).

Lasky, Melvin y Bondy, François, La Révolution hongroise: histoire du soulèvement d'octobre, Plon, Paris, 1957. 
Lechner, Noberto, "De la revolución a la democracia", en Los patios interiores de la democracia: subjetividad y politica, FCE, México, 1995.

Lefort, Claude, "L'insurrection hongroise": Socialisme ou barbarie, n. 20 (diciembre 1956), pp. 85-116.

-, "La méthode des intellectuels progressistes", en Éléments d'une critique de la bureaucratie, Gallimard, Paris, 1979.

_, "Le totalitarisme sans Staline", en Éléments d'une critique de la bureaucratie, Gallimard, Paris, 1979.

—, "Le próletariat et sa direction", en Éléments d'une critique de la bureaucratie, Gallimard, Paris, 1979.

—, "Organisation et Parti", en Éléments d'une critique de la bureaucratie, Gallimard, Paris, 1979.

—, "La contradiction de Trotski", en Éléments d'une critique de la bureaucratie, Gallimard, Paris, 1979.

_., "Hannah Arendt et la question du politique", en Essais sur le politique, Seuil, Paris, 1986.

—, "Permanence du théologico-politique?", en Essais sur le politique, Seuil, Paris, 1986.

—, La complication. Retour sur le communisme, Fayard, Paris, 1999.

—, Le temps present, Écrits 1945-2005, Belin, Paris, 2007.

—, "Hongrie 1956. Un révélateur historique", en Le temps présent. Écrits 1945-2005, Belin, Paris, 2007.

—, "La première révolution antitotalitaire", en Le temps présent. Écrits 1945-2005, Belin, Paris, 2007.

_, "La question de la révolution”, en Le temps présent. Écrits 1945-2005, Belin, Paris, 2007. Linz, Juan, La quiebra de las democracias, Alianza, Madrid, 1987.

Marchart, Olivier, El pensamiento político post-fundacional, FCE, Buenos Aires, 2009.

Merleau-Ponty, Maurice, Signes, Gallimard, Paris, 1960.

Molina, Esteban, Le défi du politique. Totalitarisme et démocratie chez Claude Lefort, L'Harmattan, Paris, 2005.

Molnár, Miklós, Victoire d'une défaite: Budapest, 1956, L’Age de l'homme, Paris, 1996.

Plot, Martín, La carne de lo social, Prometeo, Buenos Aires, 2008.

Poltier, Hugues, Lefort y el descubrimiento de lo político, Nueva Visión, Buenos Aires, 2003.

Raflin, Marie-France, "Socialisme ou barbarie: du vrai communisme à la radicalité", tesis doctoral presentada el 13 de abril de 2005, Institut d'études politiques de Paris. Disponible en: http://spire.sciencespo.fr/hdl:/2441/53r60a8s3kup1vc9kd4rhb0q4/resources/raflinscpo-2005.pdf (septiembre 2016).

Ribeiro, Renato, La última razón de los reyes, Colihue, Buenos Aires, 1998.

Sartre, Jean Paul, "Le fantôme de Staline", en Situations VII, Gallimard, Paris, 1965.

—, "El socialismo que venía del frío", en Situación XIX, Losada, Buenos Aires, 1973.

Sirczuk, Matías, "La invención democrática. Una lectura de Lefort": Las Torres de Lucca, vol. 3, n. $^{\circ} 5$ (julio-diciembre 2014), pp. 7-23.

Tassin, Étienne, Le trésor perdu. Hannah Arendt l'intelligence de l'action politique, Paris, Payot, 1999. 